DOI https://doi.org/10.30525/978-9934-26-114-5-45

\title{
РЕАЛІЗАЦІЯ ПРИНЦИПУ РОЗВИТКУ ПАРТНЕРСЬКОЇ ВЗАЕМОДІЇ У ПРОЦЕСІ ПІДГОТОВКИ МАЙБУТНЬОГО ФАХІВЦЯ СОЦІОНОМІЧНОЇ СФЕРИ
}

\author{
Віцукаєва К. М. \\ доцент кафедри педагогічних технологій початкової освіти \\ Південноукраїнський національний педагогічний університет \\ імені К. Д. Ушинського \\ м. Одеса, Украӥна
}

Поширення соціономічних професій у сучасному суспільстві взагалі та у сфері освіти зокрема, зумовлює необхідність усебічного вивчення професії типу «людина-людина» та розробленню методичного забезпечення підготовки означених фахівців. Таким чином, пошук нових підходів, методів та засобів, що забезпечують успішність та ефективність процесу підготовки майбутнього фахівця соціономічної сфери як суб'єкта професійної діяльності є важливою сучасною проблемою.

Отже, у процесі підготовки майбутніх фахівців соціономічної сфери (соціальних педагогів) було реалізовано принцип розвитку партнерських взаємодій, який регулює конструювання й використання методів розвитку системи відносин. Цей принцип передбачає педагогічне стимулювання механізмів суб'єктифікації [1] партнерів по взаємодії психологічних механізмів, які дозволяють іншим «відкритися» для особистості як суб'єктів, сприяють формуванню «суб'єктної настанови» стосовно інших, що кардинально змінює суб'єктивне ставлення до них, а також сам характер взаємодії.

Характер розвитку партнерських взаємодій найповніше визначають такі поняття, як співробітництво, включення, участь, навчання, партнерство. Поняття партнерства відображає, на нашу думку, ідеальний тип спільної діяльності викладача та студентів і студентів один 3 одним. Партнерство має на увазі довіру, обмін знаннями, навичками й досвідом допомоги студентам у їхньому соціальному розвитку. Тобто це такий стиль відносин, що дозволяє ставити загальні цілі й досягати їх з більшою ефективністю, ніж тоді, коли учасники діють ізольовано один від одного. Встановлення партнерських відносин вимагало від викладача часу й певних зусиль, досвіду, знань. Тут важливо допомогти студентам і викладачу зрозуміти один одного й правильно оцінити ситуацію, створити толерантні й доброзичливі відносини. 
Взаємодія виступала джерелом розвитку суб'єктів спільної діяльності. Людина як суб'єкт взаємодії характеризується чітко вираженою активністю, ініціативою у взаємодії з іншими елементами (об'єктами, суб'єктами) процесу, тобто, за визначенням К. АбульхановоїСлавської, О. Леонтьєва і С. Рубінштейна, всіма ознаками діяльнісної основи. Використовуючи як методичний принцип - принцип розвитку партнерських відносин, ми виявили, що процес засвоєння знань зумовлений не тільки змістом навчального предмета, але й, в не меншому ступені, динамікою форм відносин викладача зі студентом і студентів один з одним. Зокрема, порушення адекватності цих форм у структурі освоюваної діяльності призводило до перебудови мотивів, зміні змісту навчання й навіть до його втрати.

Принцип розвитку партнерських взаємодій побудований на підставі методів розвитку системи відносин, до якої належать:

- метод розвитку ідентифікації (лат. identificare - ототожнювати) постановка особистістю себе на місце того або того об'єкта, занурення в ситуацію, простір, обставини, у яких об'єкт перебуває, психологічне моделювання стану об'єкта. Цей метод використовувався нами у процесі проведення рольових ігор, де студентам пропонувалося поставити себе, наприклад, на місце: дитини, що пережила жорстоке поводження. Власні відчуття в цій ситуації проектуються студентом на стан дитини. Використання цього методу не тільки створює ситуацію ототожнення себе 3 різними об'єктами, але й сприяє формуванню бажання займатися соціально-педагогічною діяльністю.

- метод розвитку емпатії (грец. erapatheia - співпереживання) співпереживання особистістю стану об'єкта, співчуття йому через ототожнення 3 ним, а також переживання власних почуттів і емоцій відносно об'єктів. Метод емпатії полягає в педагогічній актуалізації співпереживання особистістю стану об'єкта, а також співчуття йому. Цей метод стимулює перенесення особистістю власних станів на об'єкти; переживання тих або тих станів, які випробовує інша людина, через ототожнення 3 нею, а також переживання власних емоцій відносно стану об'єктів, тобто прояв співчуття.

Для актуалізації прояву емпатії до інших людей, нами використовувалися різні ситуації, що призивають студентів до відповіді на запитання: «Що зараз відчуває та або та людина?», «Який у неї зараз настрій?», «Що в цей момент може створювати ій незручності?» тощо. Залучення студентів до співпереживання іншим людям сприяє суб'єктифікації об'єктів, що, у свою чергу, зумовлює характер суб'єктивних відносин студента до довколишнього світу, формує в нього таку якість суб'єкта, як розуміння й прийняття інших. 
- метод розвитку рефлексії (лат. reflexio - звернення назад) полягає в педагогічній актуалізації аналізу студентом своїх i чужих дій i вчинків, з погляду доцільності, міститься в педагогічній актуалізації самоаналізу особистістю своєї поведінки стосовно інших.

Рефлексивна діяльність - це внутрішній процес мислення (думання про себе), що і забезпечує розвиток особистості. Ми не трактуємо рефлексію як спостереження людини над самою собою (у результаті чого стають можливими самоаналіз, самооцінка, самовиховання тощо). Нами рефлексія розуміється як саморозуміння й розуміння іншого, самооцінка й оцінка іншого, самоінтерпретація й інтерпретація іншого тощо. Дійсно, рефлексивна думка може бути спрямована не тільки на пізнання себе, той же рух по колу відбувається під час осмислення якогось соціального явища, суспільного катаклізму, факту або конкретного знання, в ході вивченні іншої людини. Рефлексивні завдання, які пропонувалися нами в межах тренінгових занять, включали творче розв'язання соціально-педагогічних завдань, які вимагали від студентів уяви, у тому числі й фантазії, логічного мислення, уміння порівнювати, виділяти частини й ціле, відрізняти суттєве від несуттєвого, бачити головне. I, звичайно ж, в основі рефлексії лежить інтуїція, знання й досвід особистості. Закон рефлексії сформульований так: в основі рефлексивного розвитку лежить знання й життєвий досвід людини.

Всі дії, всі акти інтелектуальної творчості (креативності) належать до процесів рефлексивної абстракції. Натомість, далеко не кожний, хто прийшов за студентську лаву, здатний (навчений) рефлексії.

Рефлексивні завдання насамперед формували в майбутніх фахівців соціально-творчий компонент суб'єктної діяльності. 3 огляду на це, рефлексивні завдання, запропоновані нами в системі підготовки майбутнього соціального педагога як суб'єкта професійної діяльності, спонукали їх до прояву креативності, послідовно й цілеспрямовано формували ¥ї, навчали володінню рефлексивними методами, які так необхідні у професійній діяльності соціального педагога. Прикладом може служити така ситуація. Студент забув зробити домашнє завдання. Йому було необхідно відповісти на запитання: «Що викладач міг би про тебе подумати?» У цій ситуації значення мав той факт, що студентові самому доводилося робити висновок про те, що з погляду викладача, він, безумовно, «виглядає» як безвідповідальна, необов'язкова людина. Або, інший приклад. Розглядалась соціально-педагогічна ситуація «Студент зустрів на вулиці безпритульну дитину й, із кращих спонукань, дав їй гроші». У такій ситуації роз'яснювалося, що в найкращому разі «діти вулиці» самостійно не розпоряджаються грошима, які їм дають перехожі, а в гіршому витрачають їх на 180 
наркотики або інші психоактивні речовини. Відзначаючи соціальнопедагогічну доцільність учинку студента можна підкреслити, що із професійного «погляду» він завдав шкоди дитині і не надав дійсно саме соціально-педагогічної допомоги ій. I в цьому разі його не виправдує навіть те, що він не знав про особливості життя «дітей вулиці». Цей метод, у сукупності з методом емпатії та іншими методами корекції суб'єктивного ставлення студентів до професійної діяльності, сприяє суб'єктификації об'єктів, стимулює усвідомлення студентом того, як його поведінка могла б «виглядати» 3 погляду людей, «інтересів» яких вона торкається. Цей метод відіграє одну із провідних ролей у корекції сформованого особистісно-значущого ставлення до професійної діяльності й створення мотивації вдосконалювання індивідуальних технологій взаємодії студентів з іншими людьми. Інакше кажучи, студент починає сам прагнути до того, щоб грамотно поводитись у соціумі відповідно до своєї професійної місією.

\title{
Література:
}

1. Дерябо С.Д. Природный объект как «значимый другой». Даугавпилс, 1995. 172c.

2. Ясвин В.А. Образовательная среда: от моделирования к проектированию. М: Смысл, 2001. 365с.

DOI https://doi.org/10.30525/978-9934-26-114-5-46

\section{АДАПТИВНА ТЕХНОЛОГІЯ НАВЧАННЯ ЕSР У ПОЛІКУЛЬТУРНИХ ГРУПАХ}

\author{
Добровольська Д. М. \\ кандидат філологічних наук, \\ доиент кафедри теорії та практики перекладу \\ Одеський національний університет імені I. I. Мечникова \\ Добровольська Л. В. \\ кандидат педагогічних наук, доцент, \\ доиент кафедри іноземних мов гуманітарних факультетів \\ Одеський начіональний університет імені I. І. Мечникова \\ м. Одеса, Украӥна
}

Сьогодні, коли світове суспільство висуває високі вимоги до фахівців промислових, сільськогосподарчих галузей народного 